\title{
Teste de nomeação de Boston: desempenho de uma população de São Paulo*****
}

\author{
Boston naming test: performance of Brazilian population from \\ São Paulo
}

\author{
Letícia Lessa Mansur* \\ Márcia Radanovic** \\ Gisele de Carvalho Araújo*** \\ Laís Yassue Taquemori*** \\ Lílian Lavine Greco***
}

*Fonoaudióloga.Doutora em Lingüística Professora Assistente do Departamento de Fisioterapia, Fonoaudiologia e Terapia Ocupacional da Faculdade de Medicina da Universidade de São Paulo. Endereço para correspondência: Rua Oscar Freire, 1667 - Apto. 22 - São Paulo - SP - CEP 05409-01 (lmansur@usp.br).

**Médica Neurologista. Doutora em Neurolingüística. Departamento de Neurologia da Faculdade de Medicina da Universidade de São Paulo.

***Fonoaudióloga. Aprimoramento em Neurolingüística em Fonoaudiologia da Coordenadoria de Aprimoramento de Pessoal / Fundação do

Desenvolvimento Administrativo. Hospital das Clínicas - Curso de Fonoaudiologia Faculdade de Medicina da Universidade de São Paulo.

****Pesquisa Realizada no Hospital das Clínicas - Universidade de São Paulo.

\section{Artigo de Pesquisa}

Artigo Submetido a Avaliação por Pares

Conflito de Interesse: não

Recebido em 29.11.2004.

Revisado em 15.03.2005; 07.07.2005; 26.07.2005; 26.09.2005; 07.11.2005; 31.01.2006

Aceito para Publicação em . 31.01.2006.

\section{Abstract}

Background: The Boston Naming Test is frequently used to evaluate naming deficits. The scores used in Brazil have been the same as those used in the American version. In the case of individuals with poor schooling associated to cerebral lesions, a frequent situation in our country, one runs the risk of considering a poor performance as a deficit, what in fact is a consequence of lack of knowledge and cultural deprivation. Aim: to evaluate the influence of age and schooling in the naming ability of normal individuals, from São Paulo city, in a visual confrontation task. Method: 133 normal volunteers, aged between 28 and 70 years. Results: the scores obtained in spontaneous naming were [mean (SD)]: [39.4 (9.8)]; per age group: 28 - 50 years [39.5 (10.5)], 51 - 70 years [39.1 (9.1)]; per schooling: 1 4 years [33.7 (9.6)], 5 - 8 years [36.6 (7.9)], 9 or more [47.4 (6)]. The comparison between the performances of the two age groups did not reveal any significant differences. Higher educational level determined a better performance both in spontaneous and facilitated naming. Cues of stimuli were necessary for the individuals to access the correct name, especially for the group with lower educational level. Phonemic cues, on the other hand, benefited individuals with more than eight years of formal education. The suggested cut-off score for the test to be use in Brazil was calculated by the ROC curve analysis and based on the comparison between normal and aphasic individuals. Conclusion: schooling was the variable that had the greatest influence on performance. Although the level of difficulty of a few items may, to some extent, differ between English and Portuguese, the translated version of the BNT can be used without any adaptations for the Brazilian population, provided that the level of education is taken in consideration when interpreting the results.

Key Words: Language Tests; Brazil; Age Groups; Educational Status.

\section{Resumo}

Tema: O teste de nomeação Boston é amplamente utilizado para avaliação de alterações de nomeação. Os escores usados no Brasil têm sido os mesmos da versão americana. No caso de indivíduos pouco escolarizados com lesões cerebrais, situação freqüente em nosso país, corre-se o risco de considerar déficit o que na realidade é desconhecimento e privação cultural.Objetivo: avaliar a influência da idade e escolaridade na habilidade de nomeação de amostra de indivíduos normais, da cidade de São Paulo, em uma tarefa de confrontação visual. Método: 133 voluntários normais, com idades entre 28 e 70 anos. Resultados: os escores em nomeação espontânea foram [média (DP)]: [39,4 (9,8)]; por idade: 28 - 50 anos [39,5 (10,5)], 51 - 70 [39,1 (9,1)]; por escolaridade: 1 - 4 anos [33,7 (9,6)], 5 - 8 anos [36,6 $(7,9)], 9$ ou mais $[47,4(6)]$. A comparação de desempenho entre os dois grupos de idade, não revelou diferenças significantes. Já o nível educacional mais alto determinou melhor performance tanto para a nomeação espontânea quanto para as facilitações. Pistas do estímulo precisaram ser ativadas para que o sujeito recordasse o nome correto, especialmente no grupo com menor escolaridade. Pistas fonêmicas beneficiaram os indivíduos com mais de oito anos de instrução formal. A nota de corte sugerida para uso no Brasil, foi calculada pela análise da curva ROC e baseada na comparação entre sujeitos normais e afásicos. Conclusão: A escolaridade foi a variável que mais influenciou o desempenho. Embora o grau de dificuldade de alguns itens possa em certa medida, diferir na língua inglesa e portuguesa, a aplicação da versão traduzida do TNB sem adaptações, para a população brasileira, é possível, desde que o nível educacional seja levado em conta na interpretação dos resultados.

Palavras-Chave : Testes de Linguagem; Brasil; Grupos Etários; Escolaridade. 


\section{Introduction}

The ability to name by visual confrontation is a complex process involving recognition of the visual elements (lines, bars, dots and curves), which comprises the abstract visual representation of an object and permites its recognition. The image triggers the mental representation, from our knowledge and from diverse experiences regarding the object, which is represented in our semantic system, as well as the enunciation forms available in our language. Cognitive models recognize the existence of semantic and phonetic-phonological components in the process of naming (Hillis, 2001; Scheuer et al., 2004).

Naming is one of the most extensively studied aspects of linguistic abilities, both in normal subjects (Befi-Lopes, 2000, Befi-Lopes and Galea, 2000; Scheuer et al, 2003), in subjects with atypical language development (Befi-Lopes e Rodrigues, 2001; Befi-Lopes e Gandara, 2002; Wertzner e Galea, 2002) and in those who suffered from neurological diseases, such as aphasia, right hemisphere lesions, dementia and traumatic brain injury (Chapey, 2001). A great number of tests for language disturbances diagnosis includes visual confrontation naming tasks (Morris et al., 1989; Bayles and Tamoeda, 1993; Befi-Lopes, 2000; Kaplan et al, 1983; Kaplan et al, 2001). Two kinds of errors, verbal and visual, may be observed. In this visual input task, the quality of the stimulus and the context of the presentation may induce misperceptions and misinterpretation. The frequency of occurrence of the lexical item in a certain language, in addition to its semantic and grammatical category, lexicality, regularity, age of acquisition, imageability, operativity, length and familiarity, have all been recognized as factors that may interfere in the accomplishment of the task (Raymer and Rothi, 2001). Other sociodemographic variables, such as age and education, bilingualism (Oppenheimer e Ávila, 2004) may also influence on performance, the latter being considered the single most powerful variable influencing the performance of the subjects in neuropsychological, and particularly linguistic tests (Castro-Caldas et al., 1999; Pineda et al., 2000). It is settled that illiterate people have visuoperceptual difficulties, and a great number of authors have recently studyed the effect of low education on visual perception (Reis et al., 2001). Padakannaya et al. (2002) showed that visual naming performance was influenced not only by formal education (including access to it and level achieved), but also by the reading habits, demonstrating that readers differ in naming and recall tasks

In several tests proposed to evaluate naming abilities in individuals with neurological alterations, special attention was given to verifying the frequency of the stimulus in a given language along with its visual presentation. Word-frequency is related to experience, to needs, to occupation, to culture and to numerous other factors, which determine the relevance criteria for the individual. Presenting the items in a prototypical form attempts to minimize the effects of individual experience.

One of the most frequently tests used to evaluate confrontation naming capacity is the Boston Naming Test (BNT). The test was originally applied to 104 individuals, whose ages varied between 18 and 59 years of old, and to 46 individuals with formal education, greater than 12 years old. In 2001, the sample population was increased by 15 elderly; however, there was no mention of the participants aging range nor origin. Currently, there are a great number of publication with samples ranging between 100 and 300 individuals, representing different demographic conditions. Borod's et al. study (1980) included 147 individuals and had previously determined normative data in accordance to age and education.

The BNT comprises 60 drawed items, colored in black and white, and orderly acoording to the difficulty level in English language. The pictures have been selected excluding those which have alternative acceptable names.

In the BNT Bralizilian-sample application Romero (2000) identified 10 "illustration-problems". The naming difficulties were ascribed by the author to cultural factors, and a substitution was proposed.

An aspect to be considered in brazil is the disparity of opportunity to access formal education, with a high number of the population which do not attend school longer than four years, and on which about there is no available published data. In case of individuals with short formal education and cerebral lesions, there is a risk of a deficit predication in place of some ignorance and cultural deprivation.

The aim of this study is to evaluate the influence of ageing and formal education on the capacity of 
sample naming in a task of visual confrontation, in normal individuals from São Paulo city.

\section{Method}

The participants of this study signed a term of consent and this study was approved by the Research Committee from the Department of Physiotherapy, Speech and Hearing Pathology and Occupational Therapy of the Faculty of Medicine of the University of São Paulo (no. 359/04).

The Portuguese version of the BNT was applied to 133 Brazilian volunteers (95 women and 38 men), who were health and daily life activities independent, with no neurological or psychiatric antecedents, Brazilian Portuguese native speakers, and have lived in São Paulo more than 10 years.

Subjects were enlisted by speech therapy students' relatives, hospital employees, and outpatients' relatives or caregivers, in order to form groups that could represent the age and the schooling influences on the performance of normal individuals.

Postgraduated speech therapy students applied the BNT following the administration procedures described by Kaplan et al. (1983), with the supervision of a Speech Therapy professor. In accordance with the instructions of the authors, the drawings were presented permitting the subject 20 seconds for the response, which was registred in the pertinent column every time it was correct or not. If the individual gave an answer which could indicate an error in the perception of the drawing, a stimulus clue was provided, as indicated by the authors of the test. The phonemic clue consisted of providing the initial sound of the target word, underlined on the answer sheet, which was usually the first consonant and vowel sound of the item. If the individual was succeed on completing the word correctly after the phonemic clue it was duly noticed in the pertinent column; in the other cases the answer was likewise registered. The subject's initial answers were computed beginning with the non-clued visual stimulus, considered as spontaneous. In the case of an error or no response, in addition to the phonemic cues of the first syllable of the item, stimulus cues were provided, such as semantic category, functional or sensorial attributes, which favored the identifycation. Answers exhibiting regional variations were accepted as long as these appeared in specialized dictionaries of Brazilian Portuguese language usage Houaiss \& Villar (2001) and Borba (2001).
Data were analyzed using the MedCalc $\AA$ version 7.2.1.0 software. Subjects were divided into three groups according to their educational level: up to four years of study $(n=42)$, from five to eight years $(n=45)$ and nine or more years $(n=46)$, and into two groups according to age: from 28 to 50 years $(n=69)$ and from 51 to 70 years $(n=64)$. Age groups were compared for schooling level (ANOVA). The results obtained in the BNT for the different age and schooling groups were compared using the Student's t test and ANOVA, using the Student-Newman-Keuls post-test. The performance of the normal group was then compared to a group of 52 aphasics, in order to obtain a cut-off score differentiating the both groups, through ROC curve analysis. The aphasic patients were selected from a sample of outpatients attended at our Neurolinguistics Unit, all of them were dextrous and shared complaints involving language impairment and all presented objective alterations, both in the functional evaluation and in the Boston Diagnostic Aphasia Examination, in addition to having neuroimaging exams showing damage in the left hemisphere, affecting brain areas related to language (Radanovic et al, 2004). A value of $\mathrm{p}<0.05$ was considered statistically significant for all analyses.

\section{Results}

The age of normal subjects ranged between 28 and 70 years $(M=49.3 \mathrm{yrs} ; \mathrm{SD}=10.6 \mathrm{yrs})$, whereas educational level, defined as time devoted to formal study, was between 2 and 24 years $(M=8.3 \mathrm{yrs}$; $\mathrm{SD}=4.6 \mathrm{yrs})$. The average educational level in years for the two age-groups was: 28 to $50-\mathrm{M}=9 ; \mathrm{SD}=$ 4.8 and 51 to $70-\mathrm{M}=7.5 ; \mathrm{SD}=4.3$. There was no statistically significant difference in the average of the educational level between the groups $(\mathrm{p}=0.06)$.

The age of aphasics varied between 16 and 83 years $(M=51.4$ yrs; $S D=16.3$ yrs $)$ whereas educational level ranged between 0 and 16 years $(\mathrm{M}=7.2 \mathrm{yrs} ; \mathrm{SD}=4.8 \mathrm{yrs})$. There were no statistically significant differences for aging and schooling between aphasics and the total sample of controls ( $\mathrm{p}=0.3$ and 0.15 , respectively).

Table 1 shows the overall results over the four categories of answers in the BNT; spontaneous (answers with no cues), phonemic cues, semantic cues and total (spontaneous plus semantic cues); Table 2 shows the results distribution in percentiles. The comparing of the performance between the two age groups did not show any significant 
difference (Table 3). Higher educational level led to a better performance in all categories, except for stimulus cues, while the cut-off for schooling was eight years (Table 4). On the other hand, the subjects similarly performed in all categories when the cut-off for schooling was four years, except again, for stimulus cues (Table 5).

In Table 6, we present a suggested cut-off score for use in Brazil as calculated by the ROC curve analysis, and based on the comparison of normal subjects and aphasics.

TABLE 1. Performance of normal subjects in the BNT $(\mathrm{N}=133)$.

\begin{tabular}{c|ccc}
\hline Categoria & M (DP) & IC 95\% & Variação \\
\hline espontâneas & $39,4(9.8)$ & $37,7-41,1$ & $15-58$ \\
PF & $5,7(4)$ & $5-6,4$ & $0-16$ \\
PE & $2,1(1.9)$ & $1,8-2,5$ & $0-9$ \\
TOTAL & $41,6(9.5)$ & $39,9-43,2$ & $19-58$ \\
\hline
\end{tabular}

$\mathrm{M}=$ Mean; $\mathrm{SD}=$ standard-deviation; $\mathrm{CI}$ - confidence interval; $\mathrm{PC}=$ phonemic cue $\mathrm{SC}=$ stimulus cue.

TABLE 2. Performance of normal subjects in the BNT in percentiles $(\mathrm{N}=133)$.

\begin{tabular}{ccccccc|c|c|c}
\hline \multirow{2}{*}{ Categoria } & \multicolumn{1}{c}{ Percentil } & \multicolumn{1}{c}{100} \\
\cline { 2 - 11 } & 0 & 5 & 10 & 25 & 50 & 75 & 90 & 95 & 100 \\
\hline espontâneas & & 23 & 25 & 31 & 39 & 47 & 52 & 54 & \\
TOTAL & & 26 & 28 & 33 & 42 & 50 & 54 & 55 & \\
\hline
\end{tabular}

TABLE 3. Performance of subjects in the BNT by age group.

\begin{tabular}{cccccc}
\hline Categoria & Idade (Anos) & M (DP) & IC $95 \%$ & Variação & P \\
espontâneas & 28 a 50 & $39,5(10,5)$ & $37,2-42,2$ & $21-58$ & NS \\
& 51 a 70 & $39,1(9,1)$ & $36,8-41,4$ & $15-56$ & NS \\
PF & 28 a 50 & $5,3(4)$ & $4,3-6,2$ & $0-16$ & NS \\
& 51 a 70 & $6,2(3,9)$ & $5,2-7,2$ & $0-15$ & $0-8$ \\
PE & 28 a 50 & $2(1,7)$ & $1,6-2,5$ & $0-9$ & $23-58$ \\
TOTAL & 51 a 70 & $2,3(2,2)$ & $1,7-2,8$ & $19-56$ & NS \\
\hline
\end{tabular}

$\mathrm{M}=$ Mean; $\mathrm{SD}=$ standard-deviation; $\mathrm{CI}$ - confidence interval; $\mathrm{PC}=$ phonemic cue; $\mathrm{SC}=$ stimulus cue; $\mathrm{NS}=$ not significant. 
TABLE 4. Performance of subjects in the BNT by educational level.

\begin{tabular}{c|c|c|c|c|c}
\hline Categoria & Escolaridade (Anos) & $\mathrm{M}(\mathrm{DP})$ & IC $95 \%$ & Variação & $\mathrm{P}$ \\
\hline \multirow{2}{*}{ espontâneas } & 1 a 8 & $33,2(8,8)$ & $33,3-37,1$ & $15-55$ & $<0,001$ \\
& 9 ou mais & $47,4(6)$ & $45,6-49,1$ & $35-58$ & 0,0006 \\
PF & 1 a 8 & $6,5(3,9)$ & $5,7-7,4$ & $0-16$ & 0,38 \\
& 9 ou mais & $4(3,7)$ & $3-5,2$ & $0-13$ & $0-9$ \\
PE & 1 a 8 & $2,3(2)$ & $1,8-2,7$ & $0-8$ & $19-56$ \\
& 9 ou mais & $1,9(1,8)$ & $1,4-2,5$ & $35-58$ & $<0,0001$ \\
\hline
\end{tabular}

$\mathrm{M}=$ Mean; $\mathrm{SD}=$ standard-deviation; $\mathrm{CI}$ - confidence interval; $\mathrm{PC}=$ phonemic cue; $\mathrm{SC}=$ stimulus cue.

TABLE 5. Performance of subjects in the BNT by educational level.

\begin{tabular}{c|c|c|c|c|c}
\hline Categoria & Eescolaridade (anos) & M(DP) & IC 95\% & Variação & P \\
\hline \multirow{2}{*}{ espontâneas } & 1 a 4 & $33,7(9,6)$ & $30,7-36,7$ & $15-55$ \\
& 5 a 8 & $36,6(7,9)$ & $34,3-39$ & $22-55$ & 0,12 \\
PF & 1 a 4 & $6,4(3,7)$ & $5,3-7,6$ & $0-13$ & 0,16 \\
& 5 a 8 & $6,7(4,2)$ & $5,4-7,9$ & $0-9$ & 0,003 \\
PE & 1 a 4 & $2,9(2,4)$ & $2,1-3,6$ & $0-5$ & $19-56$ \\
TOTAL & 5 a 8 & $1,7(1,3)$ & $1,3-2$ & $33,7-39,4$ & $23-55$ \\
\hline
\end{tabular}

TABLE 6. Cut-off scores for the BNT by schooling.

\begin{tabular}{|c|c|c|c|c|c|}
\hline Categoria & Nota de Corte Sugerida & Sensibilidade & Especificidade & ASC & IC 95\% \\
\hline \multicolumn{6}{|l|}{ amostra total } \\
\hline espontâneas & 24 & 55,8 & 91 & 0,837 & 0.775 a 0.887 \\
\hline TOTAL & 27 & 61,5 & 91,7 & 0,836 & 0,775 a 0,886 \\
\hline \multicolumn{6}{|l|}{$1-8$ anos } \\
\hline Espontâneas & 23 & 55,8 & 90,8 & 0,777 & 0,698 a 0,843 \\
\hline TOTAL & 25 & 57,7 & 94,3 & 0,778 & 0,7 a 0,844 \\
\hline \multicolumn{6}{|l|}{9 ou mais anos } \\
\hline Espontâneas & 37 & 84,6 & 91,3 & 0,949 & 0,885 a 0,983 \\
\hline TOTAL & 39 & 82,7 & 93,5 & 0,946 & 0,88 a 0,982 \\
\hline
\end{tabular}

$\mathrm{AUC}=$ area under the curve; $\mathrm{CI}=$ confidence interval. 


\section{Discussion}

The first point of discussion relates to the use of the original American version, translated with no adaptation into Brazilian Portuguese, even though cultural and linguistic aspects would certainly interfere with the final results. This procedure was adopted in order to detect which items could be considered problematic for our population. These data may support further efforts to adapt the BNT to our language.

The analysis of the response in different categories (spontaneous, after phonemic cues and after stimulus cues) allows observation of subjects' difficulties in processing the perceptive-visual information and accessing the phonemic form. Thus, the correct answers obtained after stimulus cues indicate that the subject had difficulties in interpreting the drawing, while correct answers obtained after phonemic cues indicate that the subject had the semantic "knowledge", but needed some help to retrieve the "phonological" information about the presented item.

Discrepancies regarding the level of stimulus difficulty, in Portuguese and English, respectively, were worthy to note. "Knocker", for example, which is considered a word of intermediate difficulty in English, is unusual in Brazilians' vocabulary, as is its visual representation. On the other hand, "accordion" and "hammock" (of high and intermediate difficulty respectively, in English) presented no such problems for Brazilians to name.

The age variable did not influence on the performance of the subjects in our sample. The threshold between normality and a mild decline in visual naming abilities, is known to occur at the age around seventy (Obler, 2001; Tsang and Lee, 2003) in which the subjects in our sample fell under this level.

The influence of schooling became evident in the comparison of the subjects having eight years of schooling or less, versus those with nine or more years of formal education (Table 4). In contrast, groups with one to four, and five to eight, years of education had similar performance, in which both of these groups remained different from that with more than eight years of instruction (Table 5). These results mirror those observed in most tasks of the Boston Diagnostic Aphasia Examination, whereby the significant differences also emerged when comparing subjects with eight or less, versus nine or more, years of education, in the Brazilian population (Radanovic et al., 2004).
The answer facilitation after stimulus cues shows that some non-linguistic properties (either perceptual or functional) of the objects had to be activated in order to recall the correct noun, especially in the less educated group. The dependence on cross-modality information in addition to the visual, tended to disappear in direct relation to increased education level. (tables 4 and 5). Regarding these clues, it is interesting to note the lack of uniformity in the original test: some are excessively generic, offering information about supra-categories, such as "asparagus" whose cue is "something to eat", while others are restrictive, as in "it's found in Egypt", for "sphYnx". Saito and Takeda (2001) raised this question on performing a qualitative analysis of the stimulus cues in the BNT.

The benefits in retrieval of phonemic forms (using the phonemic cues) was also influenced by schooling: the lesser educated demonstrated a lack of lexical knowledge, thus making the benefits of schooling even more evident in those with more than eight years of formal instruction (Tables 4 and 5).

With regard to the properties of the visual stimuli, some studies suggest that perceptual clarity is an important factor, in the case of illness, such as aphasia as well as in situations of cultural deprivation for lexicon access (Mills et al., 1979). The schooling effect in visual confrontation naming has been revealed by Reis et al. (2001) and Petersson et al. (2001), who detected a significantly worse performance (both in accuracy and reaction times) on immediate naming of two-dimensional representations of everyday objects, when compared to naming of the actual objects, in a group of illiterate subjects. The conclusion was that formal education and learning to read and write modulate the cognitive process involved in processing two, but not three-dimensional representations of everyday objects. Moreover, the results evidenced the influence of literacy on the visual system, or the interaction between the visual and the language systems. We must take into account that the difficulties over two-dimensional representation, as well as the clearness and redundancy of the visual information, may influence performance, particularly in the less educated. However, studies with colored stimuli disclosed an improvement in subject's performance (Reis et al., 2001). 
In clinical practice, the BNT is often used as screening test in the detection of aphasia, hence the importance of verifying its sensitivity and specificity. After comparing normal subjects and aphasics, we have presented the cut-off score that best discriminates between the two groups, according to educational level. The indicated values ( 25 for the group with eight or less years of schooling, and 39 for the group with nine or more years) represent low percentages of the total of 60 items ( $42 \%$ and $65 \%$, respectively), bearing in mind that healthy individuals, ideally, are expected to have a performance level of $90 \%$ or more in most diagnostic tests, and such performance is found in the original American sample (Kaplan et al, 1983; Kaplan et al, 2001) (Table 5). These results show a great loss in sensitivity (i.e., the ability to detect real aphasics) towards subject's with low education level, although it is unlikely that the same subject will have any anomia, or will be erroneously considered as aphasic, given that his performance will remain above the cut-off score level (due to the specificity of the test)

\section{Conclusion}

As in most studies concerning sociodemographical variables and their influence on the accomplishment of neuropsychological tests, age had a lesser interference in the

\section{References}

BAYLES, K. A.; TAMOEDA, C. K. Arizona battery for communication disorders of dementia $(A B C D)$. Tucson, Arizona: Canyonlands Publishing, 1993.

BEFI-LOPES, D. M.; GANDARA, J. P. Desempenho em prova de vocabulário de crianças com diagnóstico de alteração fonológica. R. Soc. Bras. Fonoaudiol., São Paulo, v. 7, n. 1, p. 16-22, 2002.

BEFI-LOPES, D. M.; RODRIGUES, A. Verificação do vocabulário nas alterações do desenvolvimento da linguagem. J. Bras. Fonoaudiol., Curitiba, v. 2, n. 8, p. 183-190, 2001.

BEFI-LOPES, D. M. Aquisição e desenvolvimento lexicais; algumas contribuições. Acta Semiótica Et Lingüística-R. Inter. Semiótica Ling., São Paulo, v. 8, p. 155-189, 2000.

BEFI-LOPES, D. M.; GALEA, D. E. S. Análise do desempenho lexical em crianças com alteração no desenvolvimento de linguagem. Pró-Fono R. Atual. Cient., Carapicuiba (SP), v. 12, n. 2, p. 31-38, 2000. performance of subjects than schooling. We believe that there are two reasons for this outcome: first, literacy is assumed to have a strong effect on cognitive processing as a whole, with illiteracy leading to both functional and neuroanatomical alterations; second, as pointed out earlier, most changes in language skills that occur with normal ageing, do so at more advanced ages (from the seventies and onwards), An age group that was not included in our sample.

Although the difficulty degree of some items may differ in English and Portuguese languages, the translated version of the BNT may be used with no further adaptations, provided that the scores are properly adapted for the Brazilian population and that the educational level is taken into account for the interpretation of the results. Our study revealed that the instrument distinguishes aphasic and normal individuals, even those having little formal education, which is not the case if we use the American cut-off scores as a basis, a situation where we would consider those resposnses which merely reflect socio-cultural conditions as altered. If any transcultural adaptation is to be made, further qualitative studies would be necessary to indicate which items should be replaced. A shorter version of the test, using those items not influenced by educational or age variation, might be useful toward improving its sensitivity when performed by the less educated.

BORBA, F. S. Dicionário de usos do Português do Brasil. São Paulo: Ática, 2001.

BOROD, J. C.; GOODGLASS, H.; KAPLAN, E. Normative data on the Boston diagnostic aphasia examination, parietal lobe battery, and the Boston naming test. J. Clin. Neuropsychol., n. 2, p. 209-215, 1980.

CASTRO-CALDAS, A.; MIRANDA, P. C.; CARMO, I.; REIS, A.; LEOTE, F.; RIBEIRO, C.; DUCLA-SOARES, E. Influence of learning to read and write on the morphology of the corpus callosum. Eur. J. Neurol., v. 6, n. 1, p. 2328, 1999.

CHAPEY, R. Language intervention strategies in aphasia and related neurogenic communication disorders. 4. ed. Philadelphia: Lippincott Williams \& Wilkins, 2001.

HILLIS, A. Cognitive neuropsychological approaches to rehabilitation of language disorders: Introduction. In: CHAPEY, R. Language intervention strategies in aphasia and related neurogenic communication disorders. 4. ed. Philadelphia: Lippincott Williams \& Wilkins, 2001. cap. 22, p. 513-523. 
HOUAISS, A. E.; VILLAR, M. S. Dicionario Houaiss da Língua Portuguesa. Rio de Janeiro: Instituto Antonio Houaiss e Objetiva, 2001.

KAPLAN, E.; GOODGLASS, H.; WEINTRAUB, S. The Boston naming test. Philadelphia: Lea \& Febiger, 1983.

KAPLAN, E.; GOODGLASS, H.; WEINTRAUB, S. The Boston naming test. Philadelphia: Lippincott Williams \& Wilkins, 2001.

MILLS, R. H.; KNOX, A. W.; JUOLA, J. F.; SALMON, S. J. Cognitive loci of impairments in picture naming by aphasic subjects. J. Speech Hear. Res., v. 22, n. 1, p. 73$87,1979$.

MORRIS, J. C.; HEYMAN, A.; MOHS, R.; HUGHES, J. P.; VAN BELLE, G.; FILLENBAUM, G.; MELLITS, E. D.; CLARK, C. The consortium to establish a registry for Alzheimer's disease (CERAD). Part I. Clinical and neuropsychological assessment of Alzheimer's disease. Neurology, v. 39, n. 9, p. 1159-1165, 1989.

OBLER, L. K. Developments in the adult years. In: BERKO-GLEASON, J. The development of language. Boston: Allyn and Baco, 2001. cap. 11, p. 455-488.

OPPENHEIMER, F.; AVILA, C. R. B. Influence of bilingualism in usual word designation in naming tasks: a study with Brazilian preschoolers. Pró-Fono Rev. At. Ci., Barueri (SP), v. 16, n. 2, p. 169-178, 2004.

PADAKANNAYA, P.; DEVI, M. L.; ZAVERIA, B.; CHENGAPPA, S. K.; VAID, J. Directional scanning effect and strength of reading habit in picture naming and recall. Brain Cogn., v. 48, n. 2-3, p. 484-490, 2002.

PETERSSON, K. M.; REIS, A.; INGVAR, M. Cognitive processing in literate and illiterate subjects: a review of some recent behavioral and functional neuroimaging data. Scand. J. Psychol., v. 42, n. 3, p. 251-267, 2001.

PINEDA, D. A.; ROSSELLI, M.; ARDILA, A.; MEJIA, S. E.; ROMERO, M. G.; PEREZ, C. The Boston diagnostic aphasia examination; spanish version; the influence of demographic variables. J. Int. Neuropsychol. Soc., v. 6, n. 7, p. 802-814, 2000.
RADANOVIC, M.; MANSUR, L. L.; SCAFF, M. Normative data for the brazilian population in the Boston diagnostic aphasia examination: influence of schooling. Braz. J. Med. Biol. Res., v. 37, n. 11, p. 1731-1738, 2004.

RAYMER, A. M.; ROTHI, L. J. G. Cognitive approaches to impairments of word comprehension and production. In: CHAPEY, R. Language intervention strategies in aphasia and related neurogenic communication disorders. 4. ed. Philadelphia: Lippincott Williams \& Wilkins, 2001. cap. 23 , p. 524-550.

REIS, A.; PETERSSON, K. M.; CASTRO-CALDAS, A.; INGVAR, M. Formal schooling influences two-but not three-dimensional naming skills. Brain Cogn., v. 47, n. 3, p. 397-411, 2001.

ROMERO, S. B. Desempenho de uma amostra brasileira no teste de nomeação de Boston. [Performance of a brazilian population sample in the Boston naming test]. 2000. 193 f. Dissertação (Mestrado em Neurociências) Universidade Federal de São Paulo, São Paulo.

SAITO, A.; TAKEDA, K. Semantic cueing effects on word retrieval in aphasic patients with lexical retrieval deficit. Brain Lang., v. 77, n. 1, p. 1-9, 2001.

SCHEUER, C. I.; BEFI-LOPES, D. M.; WERTZNER, H. F. Desenvolvimento da linguagem: uma introdução. In: LIMONGI, S. C. O. Fonoaudiologia: informação para a formação. Linguagem: desenvolvimento normal, alterações e distúrbios. Rio de Janeiro: Guanabara-Koogan, 2003. v. 1, cap. 1, p. 1-18.

SCHEUER, C. I.; MANGILLI, L. D.; STIVANIN, L. Nomeação de figuras e a memória em crianças: efeitos fonológicos e semânticos. Pró-Fono Rev. At. Ci., Carapicuiba, v. 16, n. 1, p. 49-56, 2004.

TSANG, H. L.; LEE, T. M. The effect of ageing on confrontational naming ability. Arch. Clin. Neuropsychol., v. 18, n. 1 , p. $81-89,2003$.

WERTZNER, H. F.; GALEA, D. E. S. Análise da ocorrência de processos fonológicos em vocábulos inseridos em frases. J. Brasil. Fonoaud., Curitiba, v. 3, n. 10, p. 48-53, 2002. 